Portland State University

PDXScholar

Fall 1-1-2012

\title{
Relative Heart Ventricle Mass and Cardiac Performance in Amphibians
}

Gregory Joseph Kluthe

Portland State University

Follow this and additional works at: https://pdxscholar.library.pdx.edu/open_access_etds

Part of the Aquaculture and Fisheries Commons, Cardiovascular System Commons, and the Other Ecology and Evolutionary Biology Commons

Let us know how access to this document benefits you.

\section{Recommended Citation}

Kluthe, Gregory Joseph, "Relative Heart Ventricle Mass and Cardiac Performance in Amphibians" (2012). Dissertations and Theses. Paper 920.

https://doi.org/10.15760/etd.920

This Thesis is brought to you for free and open access. It has been accepted for inclusion in Dissertations and Theses by an authorized administrator of PDXScholar. Please contact us if we can make this document more accessible: pdxscholar@pdx.edu. 
Relative Heart Vetricle and Cardiac Performance in Amphibians

by

Gregory Joseph Kluthe

A thesis submitted in the partial fulfillment of the Requirements for the degree of

\author{
Master of Science \\ In \\ Biology
}

Thesis Committee:

Stanley Hillman, Chair

Jason Podrabsky

Gary Brodowicz

Portland State University

(C)2012 


\begin{abstract}
This study used an in situ heart preparation to analyze the power and work of spontaneously beating hearts of four anurans (R. marina, L. catesbeianus, $X$. laevis, $P$. edulis) and three urodeles (N. maculosus, A. tigrinum, A. tridactylum) in order to elucidate the meaning of relative ventricle mass (RVM) in terms of specific cardiac performance variables. This study also tests two hypotheses: 1) the ventricles of terrestrial species (R. marina, P. edulis, A. tigrinum) of amphibians are capable of greater maximum power outputs $\left(\mathrm{P}_{\max }\right)$ compared to aquatic species $(X$. laevis, A. tridactylum, $N$. maculosus, L. catesbeianus) and, 2) the ventricles of Anuran species (R. marina, $P$. edulis, L. catesbeianus, $X$. laevis) are capable of greater maximum power output compared to aquatic species (A. tigrinum, A. tridactylum, N. maculosus). The data supported both hypotheses. RVM was significantly correlated with $\mathrm{P}_{\max }$, stroke volume, cardiac output, afterload at $\mathrm{P}_{\max }$, and preload at $\mathrm{P}_{\max }$. Preload at $\mathrm{P}_{\max }$ and afterload at $\mathrm{P}_{\max }$ also correlated very closely with each other, suggesting that an increase blood volume and/or increased modulation of sympathetic tone may influence interspecific variation RVM and may have played a role in supporting higher rates of metabolism, as well as dealing with hypovolemic stresses of life on land.
\end{abstract}




\section{Acknowledgements}

Financial assistance provided NSF IOS-0843082 and the Forbes-Lea Fund was greatly appreciated. I would like to express my great appreciation for the advice and guidance received from my advisor Dr. Stanley Hillman, and committee members Dr. Gary Brodowicz, and Dr. Jason Podrabsky. I would also like to thank all of the amazing educators that have had in my life. Your impact on my life has been truly amazing and I will be forever indebted to you all. 


\section{Table of Contents}

Abstract .....................................................................

Acknowledgements. ....................................................... ii

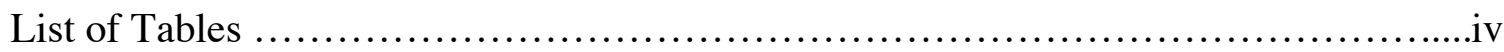

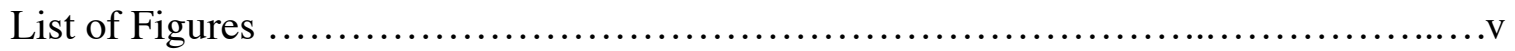

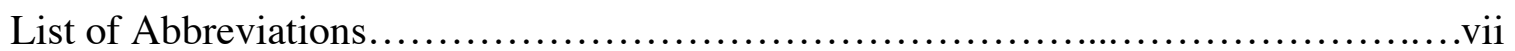

Chapter 1

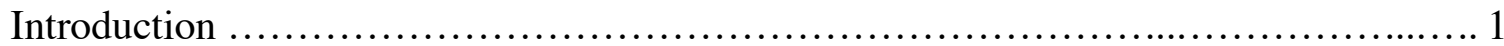

Chapter 2

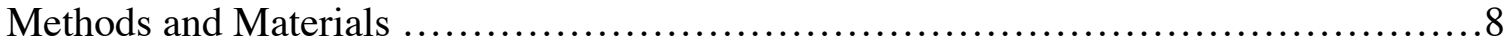

Chapter 3

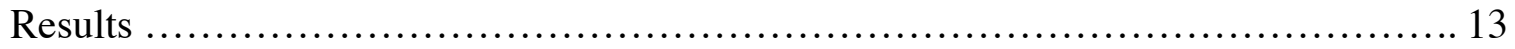

Chapter 4

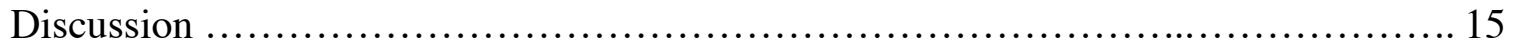

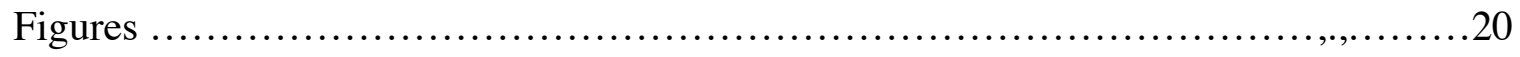

Tables................................................................... 32

References .................................................................. 33 


\section{List of Tables}

Table 1. Cardiovascular performance values at maximum myocardial power output per $\mathrm{kg}$ body mass for in situ perfused hearts Page 32

Table 2. Maximum power and work output of in situ perfused hearts...............Page 32 


\section{List of Figures}

Figure 1. Net energy cost of locomotion for swimming, flying and running animals, related to body size. Single open circle represents a swimming duck. Figure taken from Schmidt-Neilsen (1972). Page 20

Figure 2. A summary of relative ventricular mass (RVM) of amphibians (circles) and fishes (triangles). The points within ellipse represent values reported for ice fish from Antarctica, which lack hemoglobin. Page 21

Figure 3. A summary of the activity $\dot{\mathrm{V}} \mathrm{O}_{2 \max }$ measured during activity in fish (triangles) and amphibians (circles) and reptiles at $20-25^{\circ} \mathrm{C}$. Filled circle are anurans, unfilled circles are salamanders and half filled circles are caecilians. Page 22

Figure 4. Diagram of in situ perfusion preparation modified from Acierno et al. (1991). Note that the heart is actually still within the organism but is not illustrated that way for simplicity Page 23

Figure 5. Comparisons between aquatic and terrestrial species (B, D, F) and anurans and urodeles $(\mathrm{A}, \mathrm{C}, \mathrm{E})$ in terms of average $\mathrm{P}_{\max }(\mathrm{A}, \mathrm{B})$, average preload at $\mathrm{P}_{\max }(\mathrm{C}, \mathrm{D})$, and average afterload at $\mathrm{P}_{\max }(\mathrm{E}, \mathrm{F})$. Error bars represent standard error. Terrestrial species: $R$. marina, P. edulis, and A. Tigrinum. Aquatic species: X. laevis, L. catesbeianus, A. tridactylum, and N. maculosus.... .Page 24 
Figure 6. Afterload at maximum power output (A), preload at maximum power output (B), maximum power per kilogram body mass (C), Cardiac output (D), Stroke Volume (E), maximal power per gram ventricle $(F)$, maximal Work per gram ventricle $(G)$. Points represent averages individual values. Individual values were used in correlation analysis.

Page 25

Figure 7. Relationship between RVM and maximum power ouput per kg body mass (A), per g ventricle (B), and maximum work per gram ventricle $(\mathrm{C}) \ldots \ldots \ldots \ldots \ldots \ldots$. Page 27

Figure 8. The effect of afterload on cardiac output for all seven species examined. Each

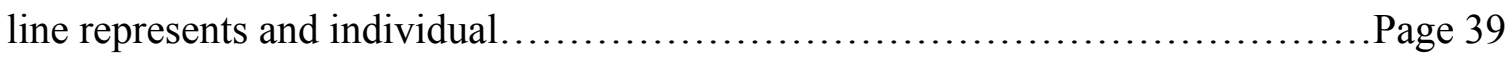

Figure 9. The effect of preload on cardiac output for all seven species examined. Each

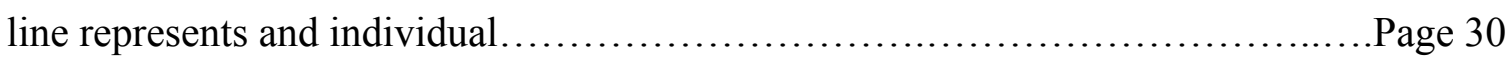

Figure 10. The effect of afterload on cardiac output for all seven species examined. Each

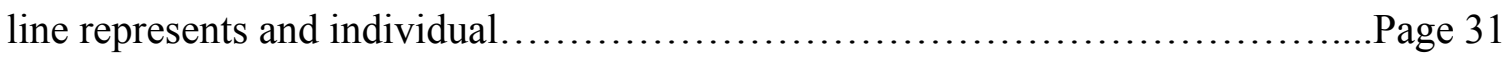




\section{List of Abbreviations}

RVM : Relative ventricle mass

$\mathrm{P}_{\text {max }}:$ Maximum cardiac output per kilogram body mass

SV : stroke volume

$\mathrm{CO}:$ cardiac output

$\dot{\mathrm{V}} \mathrm{O}_{2}$ : Volume oxygen consumed per unit time

$\dot{\mathrm{V}} \mathrm{O}_{2 \max }$ : Maximum volume oxygen consumed per unit time

Po: mean output pressure

Pi: mean input pressure

Q: flow rate

CVP: central venous pressure 


\section{Chapter 1}

\section{Introduction}

The emergence of vertebrate life on land was one of the most significant events in the evolution of vertebrates, both morphologically and physiologically. However, this colonization involved many intermediate ecological transitions that resulted in various physiological adaptations. One significant adaptation was the evolution of a rudimentary lung in fish as a way to deal with oxygen limitation often created by stagnation, warming, and/or eutrophication of shallow aquatic habitats. Fish with functioning lungs were able to exploit the stable and relatively abundant oxygen in the atmosphere. Equipped with a rudimentary lung, fish were pre-adapted colonizers, even eventually evolving more handlike lobed fins to aid in underwater locomotion where tight spaces made conventional ray-fins less useful. This remarkable array of adaptations resulted in wide speciation during the Late Devonian period, which has come to be known as the "age of the fish" (Clack, 2007; Wells, 1922).

The adaptive radiation of fish species possessing lungs and lobed fins during the "age of the fish" positioned such species well for the eventual colonization of land. The transition to a terrestrial existence offered many potential selective advantages: 1) a stable and virtually unlimited supply of oxygen, 2) escape from aquatic environments with high levels of competition, 3) escape from aquatic predators, and 4) access to terrestrial food sources. However, these benefits came with some major physiological challenges: the increased metabolic cost of terrestrial locomotion, and increased water loss and oxidative stresses. 
Schmidt-Nielsen (1972) investigated the increased metabolic cost of terrestrial locomotion by pooling existing metabolic data regarding swimming, running, and flying and expressing the data as 'cost of transport' (cal g ${ }_{\text {body mass }} \mathrm{km}^{-1}$ ). The results of this study revealed that locomotion on land is about ten times more costly than locomotion in water (Figure 1). The calculation of cost of transport from Schmidt-Nielsen is derived from metabolic rate (cal $\mathrm{g}_{\text {body mass }}^{-1}$ hour $\left.{ }^{-1}\right)$ at a given speed $\left(\mathrm{km} \mathrm{hour}^{-1}\right)$. The important consequence of this mathematical calculation is that the cost of locomotion on land or in water can be compared independent of speed. This can be applied to all non-flying vertebrates when moving at their preferred speed.

The capability of an animal to deal with an increased cost of locomotion can be estimated by determining the limitations of an animal's aerobic metabolism. Maximal aerobic capacity can be estimated by determining the maximum rate of oxygen

consumption an animal exhibits during activity $\left(\dot{\mathrm{V}} \mathrm{O}_{2 \max }\right)$. This metric is especially useful for comparing aerobic capacity among different species. An example of these interspecies comparisons can be seen in Figure 2.

When considering the colonization of land by vertebrates, speed becomes an important variable when examining a species ability to invade and populate new terrain. Vagility is a term used to describe a species capacity to disperse in a given environment and is increased by higher rates of $\mathrm{V}_{2 \max }$ (Taigen and Beuchat 1984; Burgetz et al., 1998). The capacity for vagility can be viewed from a metabolic perspective by first expressing the Schmidt-Nielsen calculation in terms of oxygen consumed per gram body weight $\left(1 \mathrm{cal}=4.19 \mathrm{ml} \mathrm{O}_{2}\right)$ per kilometer then, dividing this by the organism's $\dot{\mathrm{VO}}_{2 \max }$ 
$\left(\mathrm{ml} \mathrm{O}_{2} \mathrm{~g}^{-1} \mathrm{~km} / \mathrm{ml} \mathrm{O}_{2} \mathrm{~g}^{-1}\right.$ hour $\left.{ }^{-1}\right)$. This equation reveals that an increase in $\dot{\mathrm{VO}}_{2 \max }$ or a decrease in the metabolic cost of transport will increase vagility.

As a consequence of the variables contributing to vagility, all vertebrates faced a significant loss of vagility unless, in the context of evolutionary time, there was a simultaneous increase in $\dot{\mathrm{V}}_{2 \max }$ along with the evolution of terrestriality. Lowe (2009) further supported the importance of vagility by showing that dispersal (a subset of vagility) is especially important for species colonizing fragmented habitats which was likely the case for the first vertebrates colonizing land. However, traveling greater distances requires an increase in $\dot{\mathrm{V}}_{2 \max }$ to support movement over greater distances.

Little is known about the evolutionary changes of the vertebrate heart during the evolution of terrestriality because most research on this evolutionary transition has focused on comparing the limb morphology and physiology of extant fish to extinct amphibious fish. The fundamental flaw with this method is that fish are developmentally committed to an aquatic existence and therefore do not represent successful evolutionary solutions to a terrestrial existence (Graham and Lee, 2004). In contrast, amphibians have evolved a wide variety of effective solutions for surviving in a terrestrial world.

There are three orders within the class amphibia: urodela, gymnophiona, and anura. Urodeles are axially segmented in their musculature and move principally by lateral undulation. gymnophionans live a fossorial lifestyle, have secondarily lost all limbs and have reduced eyes and move by lateral undulation. Anurans are the most derived of the three groups with a loss of axial segmentation and well as a reduced 
number of vertebrae. Anurans are also mostly saltatory in their locomotion, meaning they move by hopping or jumping instead of the later undulation exhibited by urodeles and caecilians.

Within the class amphibia there are species of both urodeles and anurans that are aquatic, semi aquatic and terrestrial. This natural gradient from aquatic to terrestrial species provides the only living example of the cardiovascular system functioning over a spectrum of varying levels of terrestriality. For these reasons, an amphibian model is most powerful when attempting to understand the cardiovascular changes that occurred to support increased $\dot{\mathrm{V}}_{2 \max }$ during the evolution of terrestriality.

When attempting to predict where adaptations that increased $\dot{\mathrm{V}} \mathrm{O}_{2}$ may have occurred, we must first understand the overall oxygen delivery system of vertebrates. There are four general steps involved in the delivery of oxygen to active tissues in vertebrates: 1) convection brings oxygen from the environment to the lungs, 2) diffusion brings oxygen into the pulmonary capillaries, 3) cardiovascular convection delivers oxygenated blood to the systemic capillaries, 4) diffusion brings oxygen from the blood into the mitochondria. Of these four series steps one might expect to see adaptation for increased metabolic capacity in the step that provides the most resistance to $\dot{\mathrm{V}} \mathrm{O}_{2}$.

Withers and Hillman (1988) investigated which of the above steps limits $\dot{\mathrm{V}} \mathrm{O}_{2}$, by developing and testing a steady-state mathematical model of maximal oxygen and carbon dioxide transport in anuran amphibians. This model incorporated pulmonary ventilation, pulmonary diffusion capacity, cardiovascular transport capacity, and tissue diffusion 
capacity. Solutions from this model indicate that the cardiovascular convective step is the rate-limiting step of oxygen delivery in amphibians and that an increase in circulatory oxygen transport is a major physiological adaptation for increasing total $\mathrm{V}_{2}$.

Studies on fishes (Brett 1972,, Gallaugher et al., 2001; Claireaux et al., 2005; Gollock et al., 2006; Clark et al., 2008) have shown similar results. This research shows that in order to understand the evolution of increased $\dot{\mathrm{V}} \mathrm{O}_{2}$, we must first attempt to understand the maximum mechanical capabilities of the hearts of those species that made the transition to terrestriality.

Relative ventricle mass (RVM) is a convenient way to compare the size of a vertebrate's heart within and among species relative to body mass and is especially useful in the study of amphibians because ventricle mass scales isometrically within an amphibian species (Hillman et al., 2000; Withers and Hillman, 2001). Understanding what RVM means in terms of cardiovascular variables in amphibians is also especially useful because amphibians are smaller than most other vertebrate classes (Pough, 1980), which makes direct in vivo measurement very difficult using current technologies. Additionally, RVM can be measured from almost any species that exist in museum collections around the world, allowing for hypotheses to be developed based on RVM without the need for animal experimentation.

Most research on RVM in ectothermic vertebrates has focused on fishes and has revealed that the hearts of species with especially large RVM seem to utilize, to varying degrees, one of two mechanical strategies. The first strategy uses an increase in RVM to boost cardiac output primarily by increasing stroke volume. The extreme example of this 
being the ice fish family channichthyidae, which have evolved the largest relative ventricle mass of any fish and have stroke volumes six times greater than temperate fish (Tota et al., 1991). The second mechanical strategy uses an increase in RVM in order to generate greater pressures to drive the circulation of blood. Tuna hearts are an example of hearts that generate relatively high pressures while maintaining a relatively normal stroke volume because of a significant increase in heart rate.

In addition to having relatively small ventricles (Figure 2) compared to anuran amphibians, fish hearts also show morphological variation in their ventricle's physical dimensions and the proportion of compact and spongy myocardium (Ostadal 1979; Santer et al., 1983; Farrell et al., 2007, Johnston et al., 1983; Tiitu and Varnanen, 2002). Compact myocardium development is associated with the development of a coronary circulation, which is well developed in the high performing hearts of Tuna. In contrast to fishes, amphibian heart ventricles are composed entirely of spongy myocardium that receives nutrients and exchanges gases only from the blood that is pumped through the heart.

Withers and Hillman (2001) examined 42 species of anurans from formalinpreserved museum specimens. This study revealed a highly significant difference in RVM mass among the 42 species, as well as an allometric relationship between ventricle mass and body mass among species. This study reveals a three-fold variation in RVM among species of anurans. Hillman and Withers (2000) also revealed a significant correlation between RVM and dehydration tolerance in anuran amphibians. These relationships lead to a question; what does RVM actually mean in terms of cardiovascular performance? 
Research on the specific meaning of RVM in amphibians in terms of cardiac performance has been limited to a series of in situ experiments performed by Garafalo et al. (2006). These experiments provided evidence that, within an anuran amphibian species ( $R$. esculenta), greater RVM was correlated with greater ventricular pulse pressures.

Hillman and Withers (2000) conducted an extensive analysis of preserved museum specimens and revealed that there is a significant correlation between RVM and dehydration tolerance in anuran amphibians. This suggests that, along with dehydration tolerance, RVM may represent an important adaptive mechanism for life on land.

RVM has also shown to be an excellent predictor of $\dot{\mathrm{V}} \mathrm{O}_{2 \max }$ in birds and mammals (Bishop, 1997). Figure 3 shows a summary of the available data for measured $\dot{\mathrm{VO}}_{2 \max }$ in a variety of fishes and amphibians. With the exception of tuna, most fishes have a $\dot{\mathrm{VO}}_{2 \max }$ below most amphibians.

The purpose of this study is to analyze the relationship between RVM and a variety of cardiovascular properties. In addition, this study attempts to support for the hypothesis that average maximal myocardial power output is greater in anurans species compared urodele species. This study also attempts to support the hypothesis that average myocardial power output is greater in terrestrial species compared to aquatic species. 


\section{Chapter 2}

\section{Methods and Materials}

\section{Experimental Animals}

All species used in experiments, except Xenopus laevis, were wild caught and obtained from commercial suppliers. Thirteen specimens of Rhinella marina weighing between 128 and $296 \mathrm{~g}(183.1 \pm 13.5$; mean $\pm \mathrm{SE})$, eight specimens of Lithosbates catsebeianus weighing between 143 and 296 g (203.5 \pm 17.1 ; mean \pm SE), six specimens of Pyxicephalus edulis weighing between 38.0 and $49.0 \mathrm{~g}(43.3 \pm 1.6$; mean $\pm \mathrm{SE})$, and seven specimens of Ambystoma tigrinum weighing between 27.0 and $55.0 \mathrm{~g}(39.3 \pm 3.5$; mean $\pm \mathrm{SE}$ ), were housed in at $22{ }^{\circ} \mathrm{C}$ with ample water that was changed daily. Eight specimens of Amphiuma tridactylum weighing between 76.0 and $250.0 \mathrm{~g}(156.6 \pm 17.7$; mean $\pm \mathrm{SE})$, and seven specimens of $X$. lavis weighing between 55.0 and $111.0 \mathrm{~g}(80.1 \pm$ 8.8 ; mean $\pm \mathrm{SE}$ ) were housed in dechlorinated room temperature water that was changed daily. Seven specimens of $N$. maculosus weighing between 107.0 and $181.0 \mathrm{~g}$ (145.0 \pm 12.5 ; mean $\pm \mathrm{SE}$ ) were housed in dechlorinated water cooled to $14{ }^{\circ} \mathrm{C}$ and changed daily.

\section{Physiological perfusate}

The heart was perfused with a nonrecirculated solution that was composed of the following $\left(\mathrm{mmol} \mathrm{l}^{-1}\right)$ : $\mathrm{NaCl}, 110 ; \mathrm{KCl}, 2.5 ; \mathrm{CaCl}_{2}, 1 ; \mathrm{KHCO}_{3} 2.5$ Glucose 5. After mixing, the solution was titrated to a $\mathrm{pH}$ of 7.35 at $20{ }^{\circ} \mathrm{C}$ and was bubbled with air.

Heart isolation and experimental set-up for cardiac perfusion 
An in situ perfusion preparation based of techniques previously used to evaluate the mechanical performance of the heart of R. esculenta (Acierno et al. 1994) was used. The technique was modified slightly in order to further minimize the physical disturbance of the heart.

Prior to surgery animals were anesthetized using sodium bicarbonate buffered Tricaine (Ethyl 3-aminobenzoate methanesulfonate salt) then dorsally pithed and then placed on a moist paper towel, within a dissection tray, for surgery. Each animal was ventrally opened by gently dissecting the skin, musculature, sternal cartilage and/or bone, and pericardium until major vessels were exposed.

Flow through the heart was isolated by inserting polyethylene cannulae into the sinus venosus for inflow, and the conus arteriosus for outflow. All other major vessels entering the sinus venosus were occluded. The largest diameter cannula that the vessel could accommodate was used. Cannulae were secured using nonabsorbable 4-0 gauge braided silk manufactured by Surgic LC, USA. Cannulae were positioned in a way that minimized the likelihood that tissue from the vessel walls would obstruct the flow of perfusate. Low-pressure driven $(0.0-0.1 \mathrm{kpa})$ flow of perfusate began immediately upon insertion of the venous cannula so that the heart was always pumping either blood or perfusate. Total isolation time was no longer than $15 \mathrm{~min}$. Animals were not used in experiments if their heart rate did not stabilize after five minuets post cannulation. All data were collected within 60 minutes of anesthetization to avoid hearts entering a hypodynamic state (Acierno et al., 1994) 
After cannulation, mean input pressure (preload) and minimum output pressure (afterload) were regulated by adjusting the height of the input and output reservoir relative to the atrium and aortic trunk, respectively. Input and output pressures were continuously sensed using pressure transducers (Staham Physiological, model P23AC), connected via T-tubes, placed immediately before the input cannula and immediately after the output cannula. Pressure signals were continuously amplified and collected through a CB sciences, Inc ETH- 200 Bridge amplifiers and ADInstruments MacLab-8 data acquisition system. Pressure signals were calibrated with a water manometer before each experiment. Pressure measurements were expressed in $\mathrm{kPa}$ and corrected for cannula resistance. The pressure drop for the input cannula was calculated as $0.10 \mathrm{kPa}$ for R. marina and L. catesbeianus, and $0.16 \mathrm{kPa}$ for all other species. The pressure drop for the output cannula was calculated as $0.20 \mathrm{kPa}$ for R. marina, L. catesbeianus, and 0.15 $\mathrm{kPa}$ for all other species.

Cardiac output was measured by weighing perfusate output over a measured time using a hanging mass scale connected to CB sciences, Inc ETH- 200 Bridge amplifier, and continuously graphed using Maclab chart v3.6. The average slope of the graphed line was taken as the average cardiac output during the sampling time. Measurements of cardiac output were calibrated before each experiment using known volumes of perfusate. All measurements used a force-displacement transducer (model FTO3 C, manufactured by Grass Instrument Company, Qunicy, Mass. USA) and were obtained over a 30 second sampling period and hearts were allowed to adjust to new input and/or output pressures for at least 60 seconds between samples. 


\section{Terminology and Calculation}

Cardiac output was calculated as the total volume of the perfusate pumped by the heart per kilogram body mass $\left(\mathrm{ml} \mathrm{min} \mathrm{mg}^{-1}\right)$. Stroke volume $\left(\mathrm{ml} \mathrm{kg}^{-1}\right)$ was calculated from cardiac output divided by heart rate. Heart rate was determined from the output pressure pulses per 30-second sample during each experiment. In situations where pulse pressure was very low, heart rate was measured manually by visually observing the number heart beats over the 30 -second sampling period. In this study the term afterload refers to mean afterload, which was calculated as minimum afterload $+1 / 3$ maximum afterload.

Relative ventricle mass was calculated by dividing the mass of the heart ventricle by the mass the animal and multiplying the quotient by 100 . The following equations were used to calculate myocardial power output (PO) and ventricular stroke work (VSW):

$\mathrm{PO}\left(\mathrm{mWg}^{-1}\right.$ body mass $)=\left[(\mathrm{Po}(\mathrm{kPa})-\mathrm{Pi}(\mathrm{kPa})) \times \mathrm{Q}\left(\mathrm{ml} \mathrm{s}^{-1}\right)\right] /$ body mass $(\mathrm{kg})$

$\mathrm{PO}\left(\mathrm{mWg}^{-1}\right.$ ventricular mass $)=\left[(\mathrm{Po}(\mathrm{kPa})-\mathrm{Pi}(\mathrm{kPa})) \times \mathrm{Q}\left(\mathrm{ml} \mathrm{s}^{-1}\right)\right] /$ ventricular mass $(\mathrm{g})$

$\operatorname{VSW}\left(\mathrm{mJg}^{-1}\right.$ ventricular mass $)=\left[(\mathrm{Po}(\mathrm{kPa})-\mathrm{Pi}(\mathrm{kPa})) \times \mathrm{Q}\left(\mathrm{ml} \mathrm{s}^{-1}\right)\right] /$ ventricular mass $(\mathrm{g})$

where Po is mean output pressure $(\mathrm{kPa}), \mathrm{Pi}$ is mean input pressure $(\mathrm{kPa})$ and $\mathrm{Q}$ is flow rate $\left(\mathrm{ml} \mathrm{s}^{-1}\right)$. 


\section{Experimental Protocols}

Once surgery was complete and the cannulated heart was stabilized, experiments were performed to assess the maximum power capabilities of each heart by challenging it with progressively greater output pressures $(0.0 \mathrm{kPa}-8.0 \mathrm{kPa})$ at a variety of input pressures $(0.1 \mathrm{kPa}-0.8 \mathrm{kPa})$. Prior to each sample, input or output pressures were incrementally increased $(0.1 \mathrm{kPa}$ input increments, and $0.5 \mathrm{kPa}$ output increments) until myocardial power output declined or until the ventricle or atria became overstretched (see Figure 8, 9, and 10 for individual performance data). Finally, heart ventricles were removed using surgical scissors immediately after experimentation, blotted dry and weighed to yield RVM values.

\section{Statistical analyses}

A one-way ANOVA with Tukey post-hoc test was performed to compare interspecies means, and a Mann-Whitney U test was used to test null hypotheses. Correlation analysis was performed using the Pearson product-moment correlation coefficient. Statistical analyses were performed using GraphPad Prism version 5.0a for Mac OS X, GraphPad Software, San Diego California USA. A P value of less than 0.05 was considered statistically significant in all analyses. 


\section{Chapter 3}

\section{Results}

RVM varied interspecifically, with anurans having greater RVMs than urodeles, and mean RVMs ranked $R$. marina $>$ P. edulis, X. laevis, A. tigrinum $>$ L. catesbeianus $>$ A. tridactylum $>$ N. maculosus.

The in situ heart preparation described (Figure 4) was used to measure specific cardiovascular variables at maximum ventricular power per $\mathrm{kg}$ body mass $\left(\mathrm{P}_{\max }\right)($ Table 1). Individual performance curves representing $P_{\max }$ as a function of afterload (Figure 8), cardiac output as a function of preload (Figure 9), and cardiac output as a fuction of afterload (Figure 10). Mean heart rate at $\mathrm{P}_{\max }$ of A. tridactylum was significantly lower than the other six species evaluated and those six other species' average heart rates at $\mathrm{P}_{\max }$ were not significantly different. Stroke volume $\left(\mathrm{ml} \mathrm{kg}^{-1}\right.$ body mass) at $\mathrm{P}_{\max }$ varied interspecifically and positively correlated with RVM $(\mathrm{r}=0.35, \mathrm{P}<0.01)$. Cardiac output $\left(\mathrm{ml} \mathrm{min}{ }^{-1} \mathrm{~kg}^{-1}\right)$ at $\mathrm{P}_{\max }$ varied interspecifically and correlated with $\mathrm{RVM}(\mathrm{r}=0.35, \mathrm{P}<$ 0.01). Afterload at $\mathrm{P}_{\max }$ varied interspecifically and positively correlated with $\mathrm{RVM}(\mathrm{r}=$ $0.73, \mathrm{P}<0.01)$. Preload at $\mathrm{P}_{\max }$ varied interspecifically and positively correlated with RVM $(r=0.65, P<0.01)$. Also, afterload at $P_{\max }$ correlated with Preload at $P_{\max }(r=0.65$, $\mathrm{P}<0.01)$. Terrestrial species had significantly greater average preload and afterload at $\mathrm{P}_{\max }$ than aquatic species $(\mathrm{P}<0.01)$ (Figure 5: D, F). The same was true for anurans compared to urodeles $(\mathrm{P}<0.01)$ (Figure 5: C, E). 
Maximum values for ventricular power output adjusted for ventricle mass, $\mathrm{P}_{\max }$, and maximum work adjusted for ventricle mass were all measured (Table 2). All measures of power and work varied interspecifically but only $\mathrm{P}_{\max }$ significantly positively correlated with RVM $(\mathrm{r}=0.50, \mathrm{P}<0.01) . \mathrm{P}_{\max }$ was also found to be significantly greater in terrestrial species compared to aquatic species and in anurans compared to urodeles (Figure 5: B, A) 


\section{Chapter 4}

\section{Discussion}

There was significant interspecific variation RVM in amphibians, which has previously been shown to positively correlate with increased terrestriality and $\dot{\mathrm{V}} \mathrm{O}_{2 \max }$ (Hillman, 2001). These data also support the hypothesis that maximum power output per $\mathrm{kg}$ body mass $\left(\mathrm{P}_{\max }\right)$ would be greater in terrestrial species and anuran species when compared to aquatic species and urodeles, respectively. These are the first data to document what this variation may mean in terms of specific cardiovascular performance properties. The primary finings in this study revealed that RVM shows a significant correlation with both preload and afterload at $\mathrm{P}_{\max }$. Preload at $\mathrm{P}_{\max }$ and afterload at $\mathrm{P}_{\max }$ also significantly correlated with each other. These data suggest an increase in blood volume, modulation of vascular compliance, and total peripheral resistance may have played significant roles in selecting for increased RVM during the evolution of terrestriality in amphibians.

$$
\text { Flow }=\frac{\Delta \text { pressure }}{\text { resistance }} \quad \therefore \quad \Delta \text { pressure }=\frac{\text { flow }}{\text { resistance }}
$$

Hearts that are capable of generating greater pressure are better able to increase flow and are better able to handle increases in resistance, like would be seen due to increases in blood viscosity during dehydration. 


$$
\begin{gathered}
\text { Compliance }=\text { Original volume } x \frac{\Delta \text { volume }}{\text { Original volume }} \times \frac{1}{\Delta \text { pressure }} \\
\Delta C V P=\frac{\Delta \text { volume }}{\text { Compliance }}
\end{gathered}
$$

As a consequence of the factors contributing to changes in vascular pressures, species with greater vascular compliance will show less of a decrease in pressure (preload) when experiencing a loss of plasma volume, which is seen during dehydration. Also, an increase in sympathetic venous tone would allow these species to maintain cardiac output via the Frank-Starling law of the heart.

The present study has shown that there is a significant positive correlation between RVM and preload. In mammals, about 70 percent of the total blood volume is found in the venous system (Blakemore and Jennett, 2001) the mobilization of which is accomplished by neurohumoral modulation of vascular tone (Conklin et al., 1997, Hoagland et al., 2000, Olsen et al., 1997, Sandblom et al., 2005). In amphibians, a similar modulation is especially important during exercise (Romero, et al., 2004) in order to prevent excess pooling of blood on the venous side of the circulation, which occurs because the walls of venous vessels are more distensible compared to arterial vessels. Since blood volume and compliance are both greater in the venous vasculature than in the arterial vasculature, changes in filling pressures most likely reflect changes in one or both of these two variables.

Neurohumoral modulation of venous compliance may be an important mechanism utilized by amphibians in order to maintain cardiac output in the face of increased blood 
viscosity brought about by a loss of plasma volume due to dehydration. This would agree with the results showing a greater preload at $\mathrm{P}_{\max }$ in terrestrial amphibian species. Experiments by Withers et al. (1988) support this possibility by showing that dehydration and hemorrhage induced catecholamine release, which causes vasoconstriction in amphibians, was significantly greater in a terrestrial anuran species (R. marina) compared to an aquatic species (L. catesbeianus). Terrestrial species may have ventricles with greater relative mass in order to produce the greatest power when preloads are increased by catecholamine-mediated vasoconstriction. This would enable terrestrial species' cardiovascular systems to augment cardiac output during exercise, dehydration, or increases in blood viscosity. Previous research has shown that the totally aquatic urodele species N. maculosus lack any venous sympathetic tone (Axelsson, 1989), further supporting a role of the modulation of venous compliance in the evolution of terrestriality

Gravity and locomotor-modality may also play a role in selection for increased preloads in terrestrial amphibians. In the present study, average preloads of terrestrial and aquatic species were found to be significantly different (Figure 5D). The greater influence of gravity on land may have necessitated a counteracting mechanism to maintain optimal filling pressures (preload) during movement involving sudden acceleration or deceleration (e.g. the saltatory locomotion exhibited by anurans). The present study shows that species that move using saltatory motion (anurans) have significantly greater optimal preload values than species moving by undulatory motion exhibited by urodeles. 
The present study has also shown a significant positive correlation between RVM and afterload. This, in addition to the correlation between RVM and preload, and the correlation between increased afterload and increased preload among species (Figure 6H) may be the result of a larger total blood volume in species with greater RVM in order to support greater $\dot{\mathrm{V}}_{2 \max }$ needed for locomotion on land. Data showing that $R$. marina have a significantly greater blood volume than L. catesbeianus $\left(84.5 \mathrm{~mL} \mathrm{~kg}^{-1}\right.$ vs. $61 \mathrm{~mL}$ $\left.\mathrm{kg}^{-1}\right)$, and significantly greater vascular compliance $\left(47.3 \mathrm{ml} \mathrm{kg}^{-1} \mathrm{kPa}^{-1}\right.$ vs. $27.1 \mathrm{ml} \mathrm{kg}^{-1}$ $\mathrm{kPa}^{-1}$ ), support this line of reasoning (Hillman et al., 2010). In addition L. catesbeianus and R. marina have been shown to have very similar total vascular resistances (Kohl, 2009), which could explain why $R$. marina seems to have a heart ventricle adapted to pump against a greater afterload at significantly greater preloads than $L$. catesbeianus.

The present study has shown a small but statistically significant positive correlation between RVM and cardiac output, as well as RVM and stroke volume. Most fish increase stroke volume (SV) to a greater degree than heart rate (HR) in order to increase cardiac output $(\mathrm{CO})$ and have been shown to be more sensitive to the FrankStarling mechanism than amphibians and most other vertebrates (Farrell, 1984). In contrast amphibians modify HR to a greater degree than SV and it has been suggested that maintaining SV at greater afterloads may have been a more important selective pressure on amphibians than any selective pressure to increase SV (Farrell, 1991). The relatively strong positive correlation of RVM and afterload combined with the relatively weak positive correlation of RVM and CO (Figure 6D) supports this generalization regarding amphibians. 
When species data from the present study are integrated with existing species data regarding the relationship between RVM and measurements of $\mathrm{P}_{\max }$ or maximum work, $\mathrm{P}_{\max }$ per kg body mass stands out as the strongest correlate. $\mathrm{P}_{\max }$ per $\mathrm{kg}$ body mass was also the strongest correlate of RVM within the present study when individual samples were considered. RVM showed the strongest correlation with $\mathrm{P}_{\max }$ when corrected for body mass alone, which suggests that performance of the heart is related to, among other things, the overall structure of the body and vasculature and cannot simply be explained by examining heart tissue mass alone. 


\section{Figures}

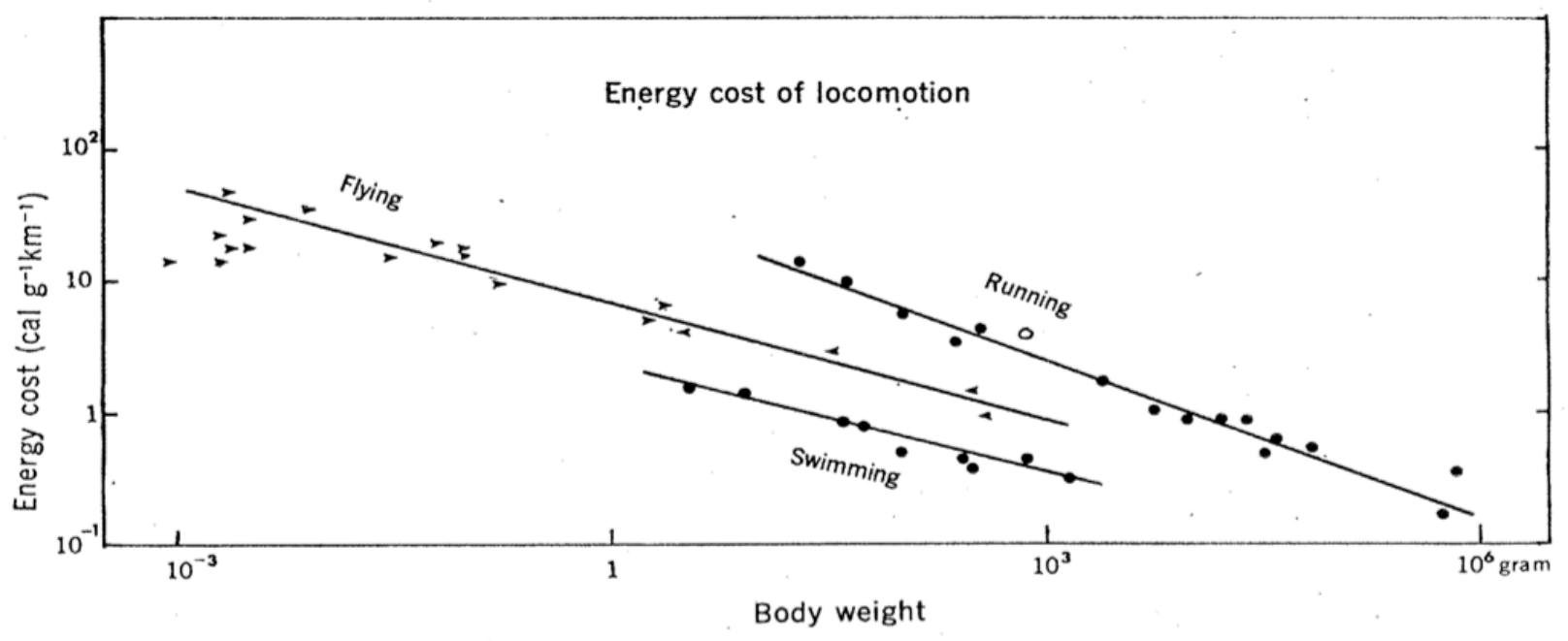

Figure 1. Net energy cost of locomotion for swimming, flying and running animals, related to body size. Single open circle represents a swimming duck. Figure taken from Schmidt-Neilsen (1972). 


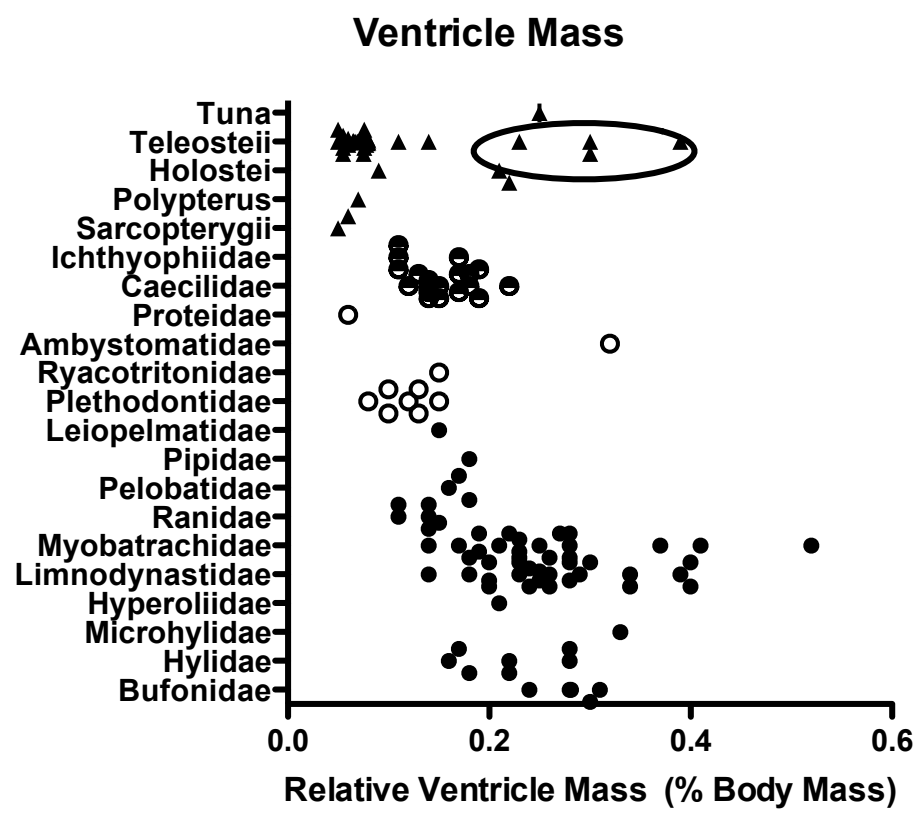

Figure 2. A summary of relative ventricular mass (RVM) of anurans (circles) and fishes (triangles). Filled circle are anurans, unfilled circles are salamanders and half filled circles are caecilians. $\eta$ The points within ellipse represent values reported for ice fish from Antarctica, which lack hemoglobin. 


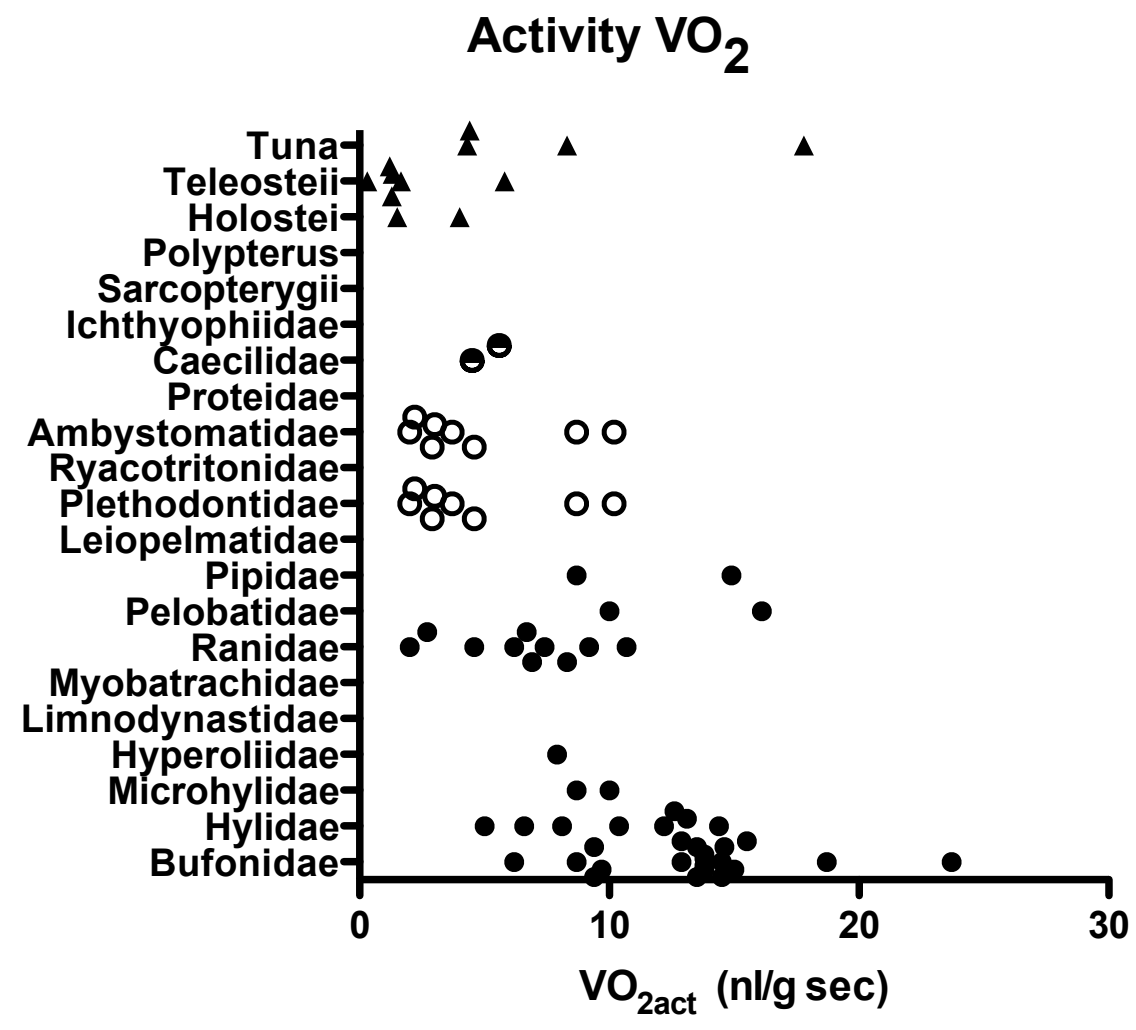

Figure 3. A summary of $\dot{\mathrm{V}} \mathrm{O}_{2}$ measured during activity in fish (triangles) and amphibians (circles) at $20-25^{\circ} \mathrm{C}$. Filled circle are anurans, unfilled circles are salamanders and half filled circles are caecilians. Data for amphibians were extracted from the summary of Gatten et al. 1992, Smits and Flanigan 1994. Data for fish are derived from Gooding et al. 1981, Dewar and Graham 1994, Farmer and Jackson 1998, Gallaugher et al. 2001, Farrell et al. 2007, Blank et al. 2007, Hillman and Withers 1987, Martin and Lighton 1989, Gamperl et al. 2002, Brett 1972. 


\section{In situ perfusion preparation}

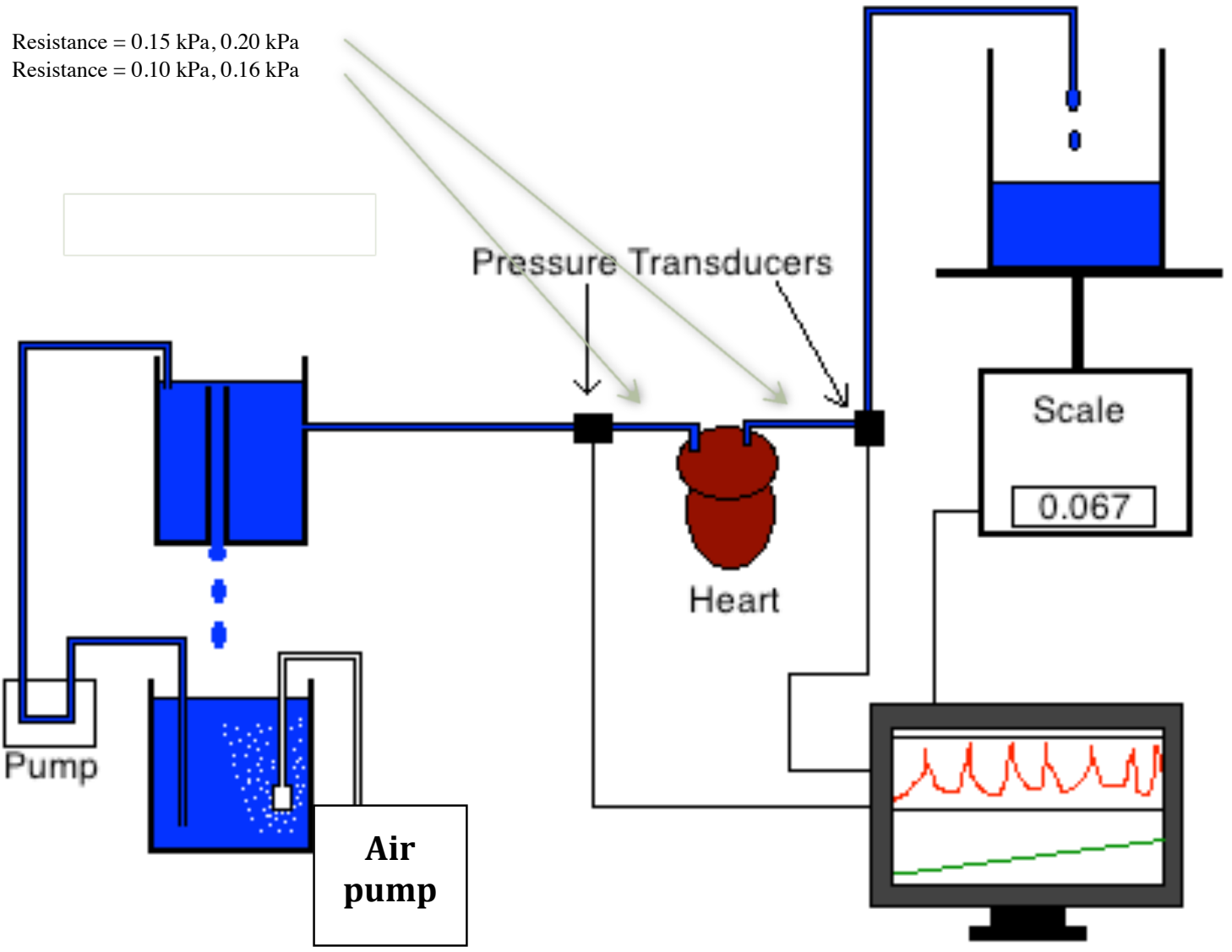

Figure 4. Diagram of in situ perfusion preparation modified from Acierno et al. (1991). Note that the heart is actually still within the organism but is not illustrated that way for simplicity. 

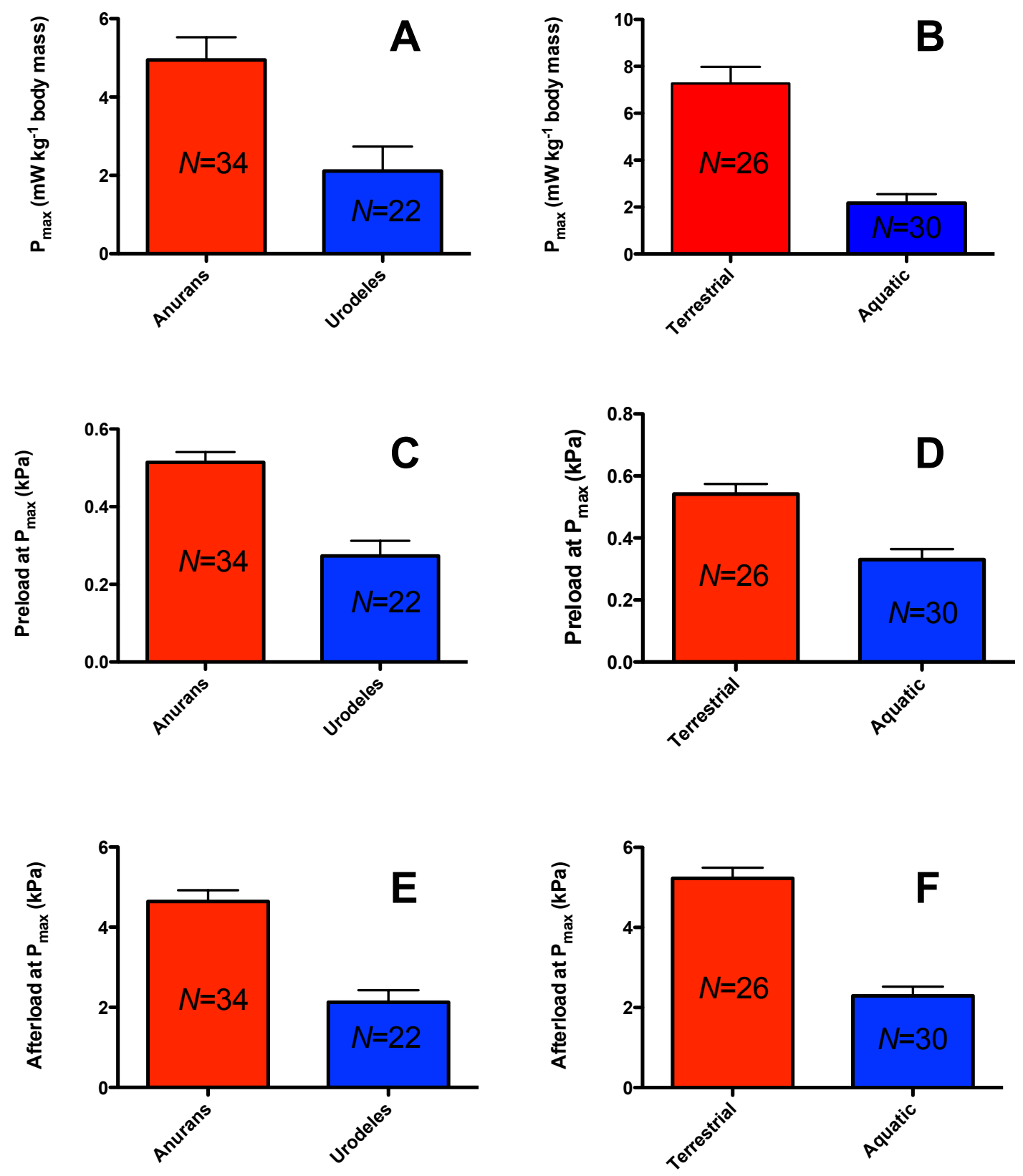

Figure 5. Comparisons between aquatic and terrestrial species $(B, D, F)$ and anurans and urodeles $(\mathrm{A}, \mathrm{C}, \mathrm{E})$ in terms of average $\mathrm{P}_{\max }(\mathrm{A}, \mathrm{B})$, average preload at $\mathrm{P}_{\max }(\mathrm{C}, \mathrm{D})$, and average afterload at $\mathrm{P}_{\max }(\mathrm{E}, \mathrm{F})$. Error bars represent standard error. Terrestrial species: $R$. marina, P. edulis, and A. Tigrinum. Aquatic species: X. laevis, L. catesbeianus, $A$. tridactylum, and N. maculosus. 

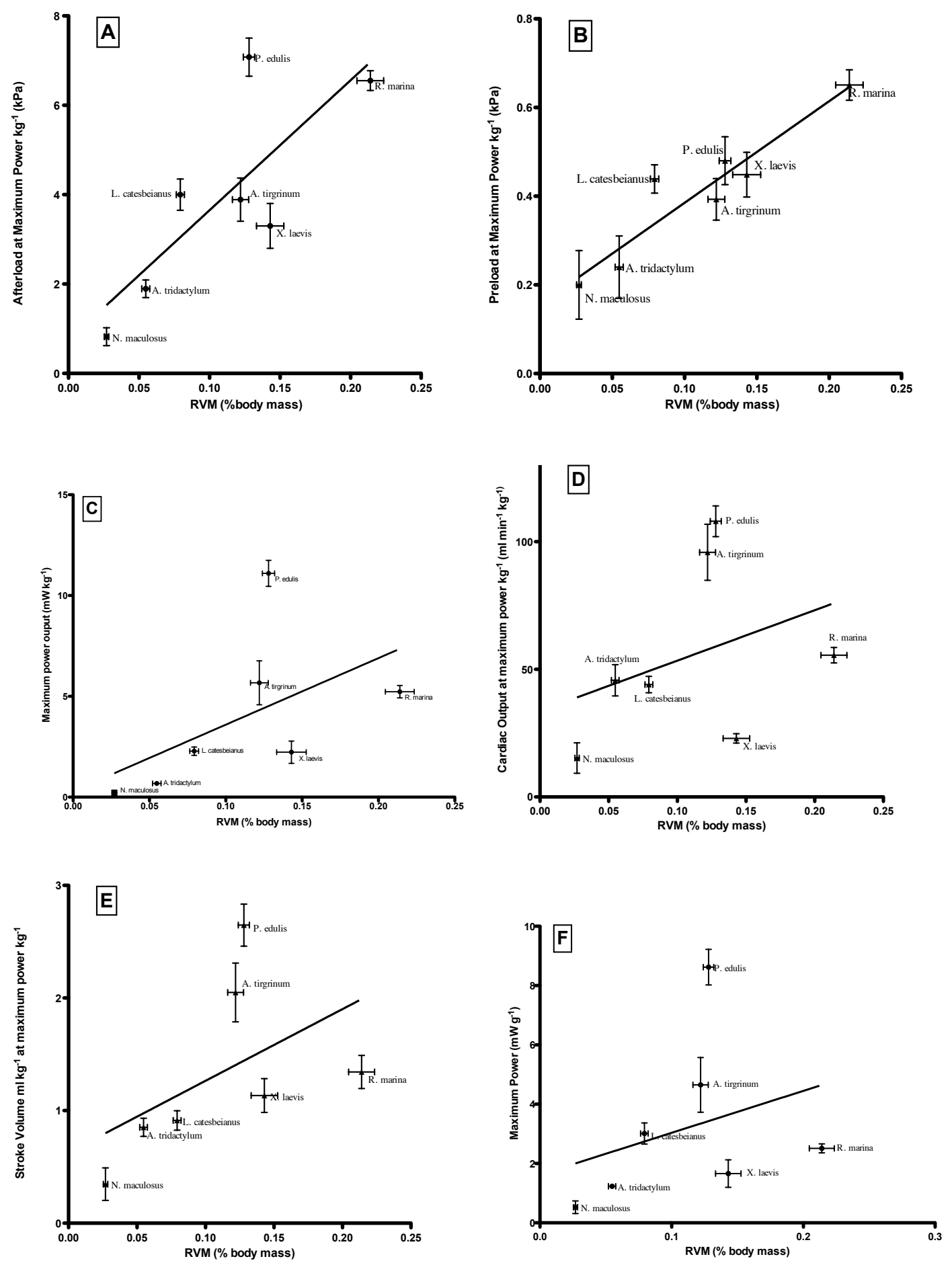

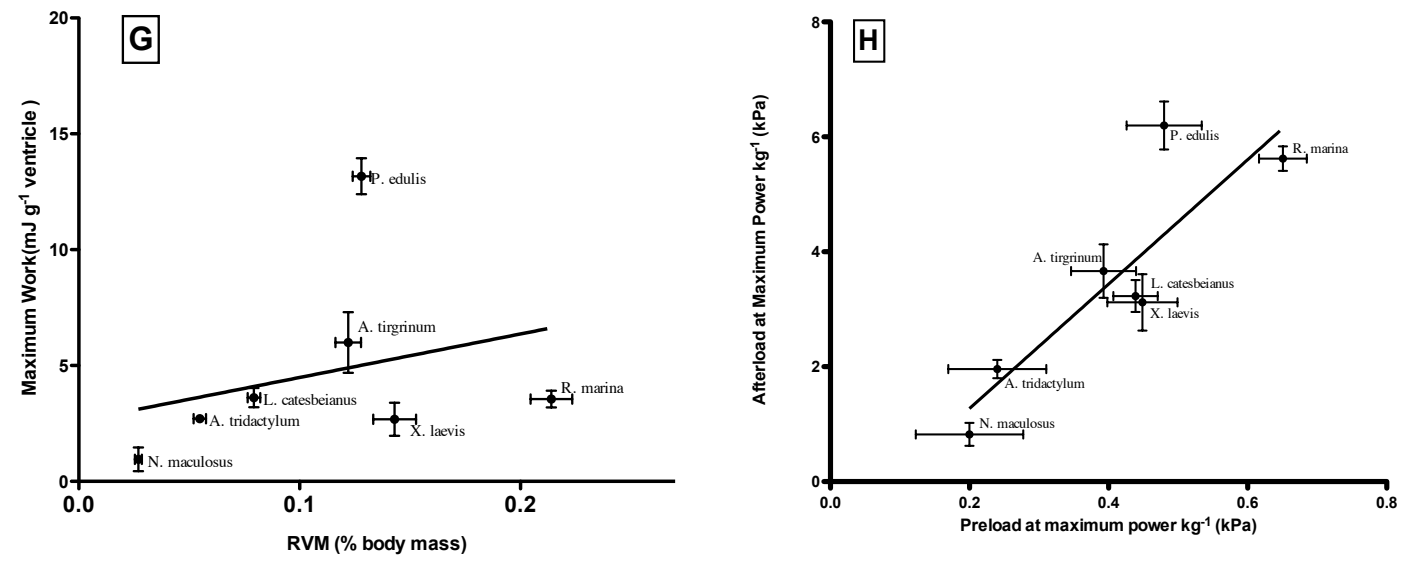

Figure 6. Afterload at maximum power output (A), preload at maximum power output (B), maximum power per kilogram body mass (C), Cardiac output (D), Stroke Volume (E), maximal power per gram ventricle $(F)$, maximal Work per gram ventricle $(G)$. Points represent averages individual values. Individual values were used in correlation analysis. 

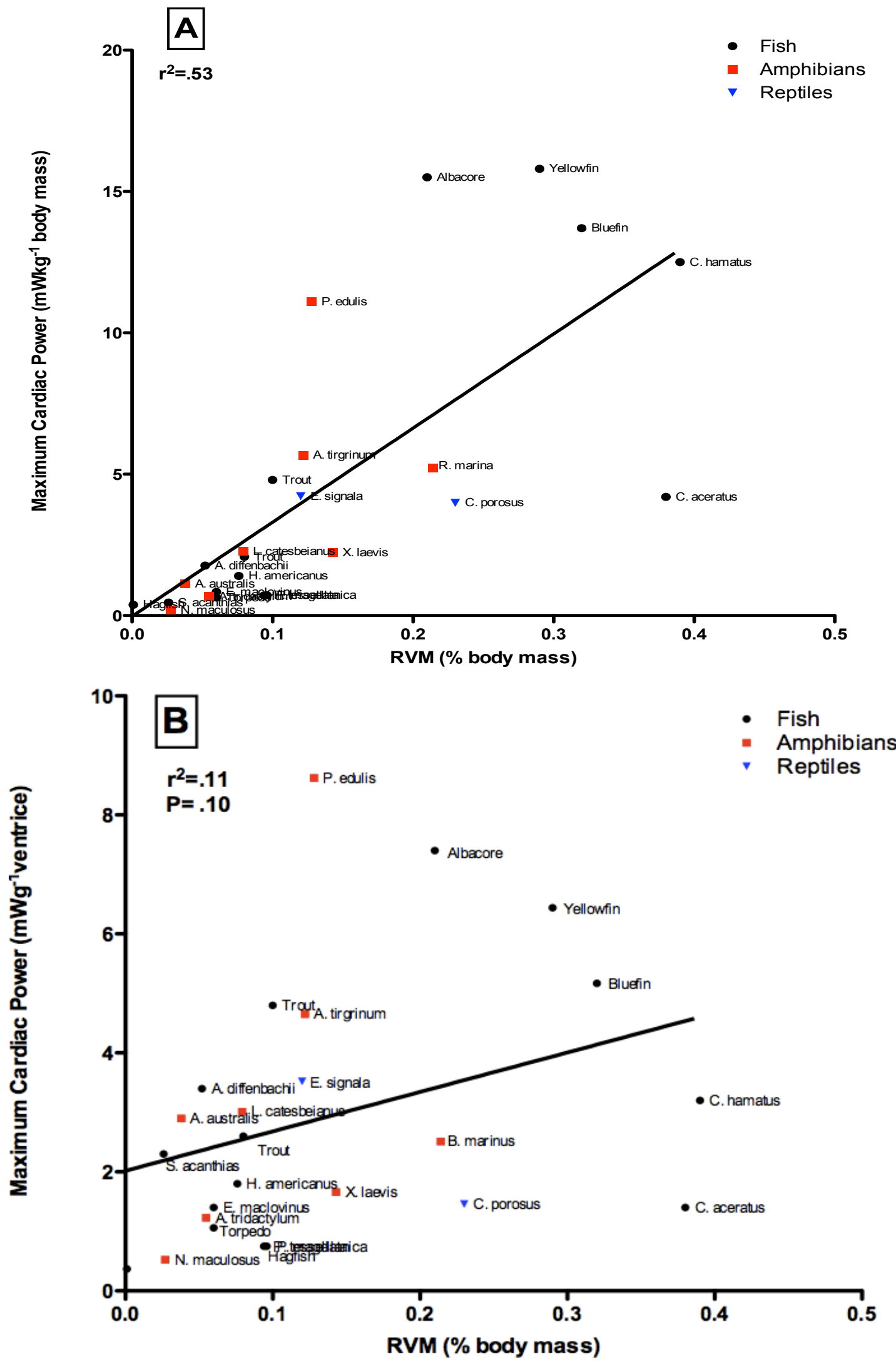


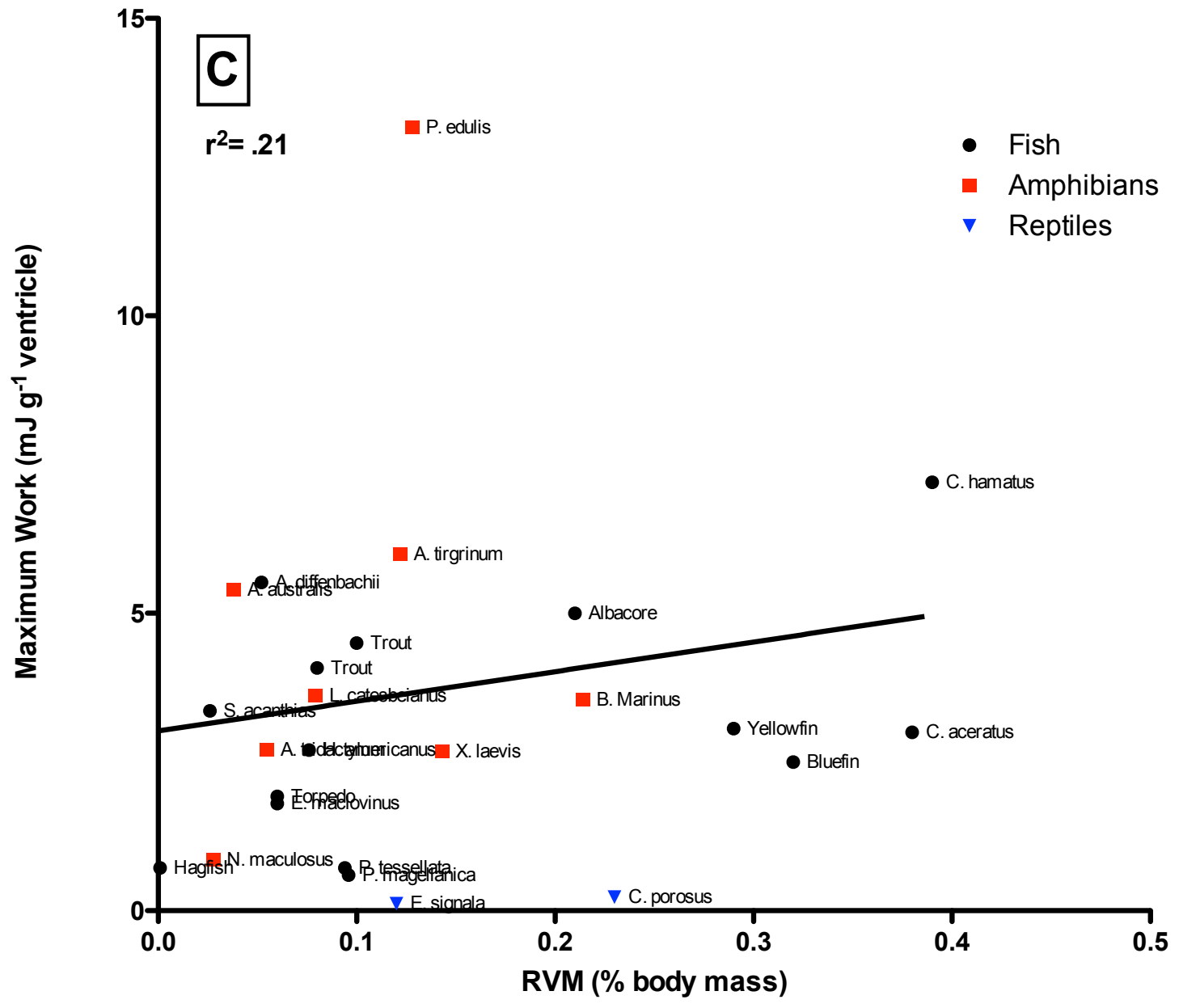

Figure 7. Relationship between RVM and maximum power ouput per kg body mass (A), per g ventricle (B), and maximum work per gram ventricle (C). Non-amphibian data were extracted from Forster, 1989; Agnisola et al. 1994; Angisola et al. 1997; Tota et al. 1991; Acierno et al. 1997; Davie and Franklin 1991; Davie et al. 1992; Davidson and Davie 2001; Farrell et al 1983; Graham \& Farrell 1989; Franklin 1994; Franklin and Axelsson 1994. 

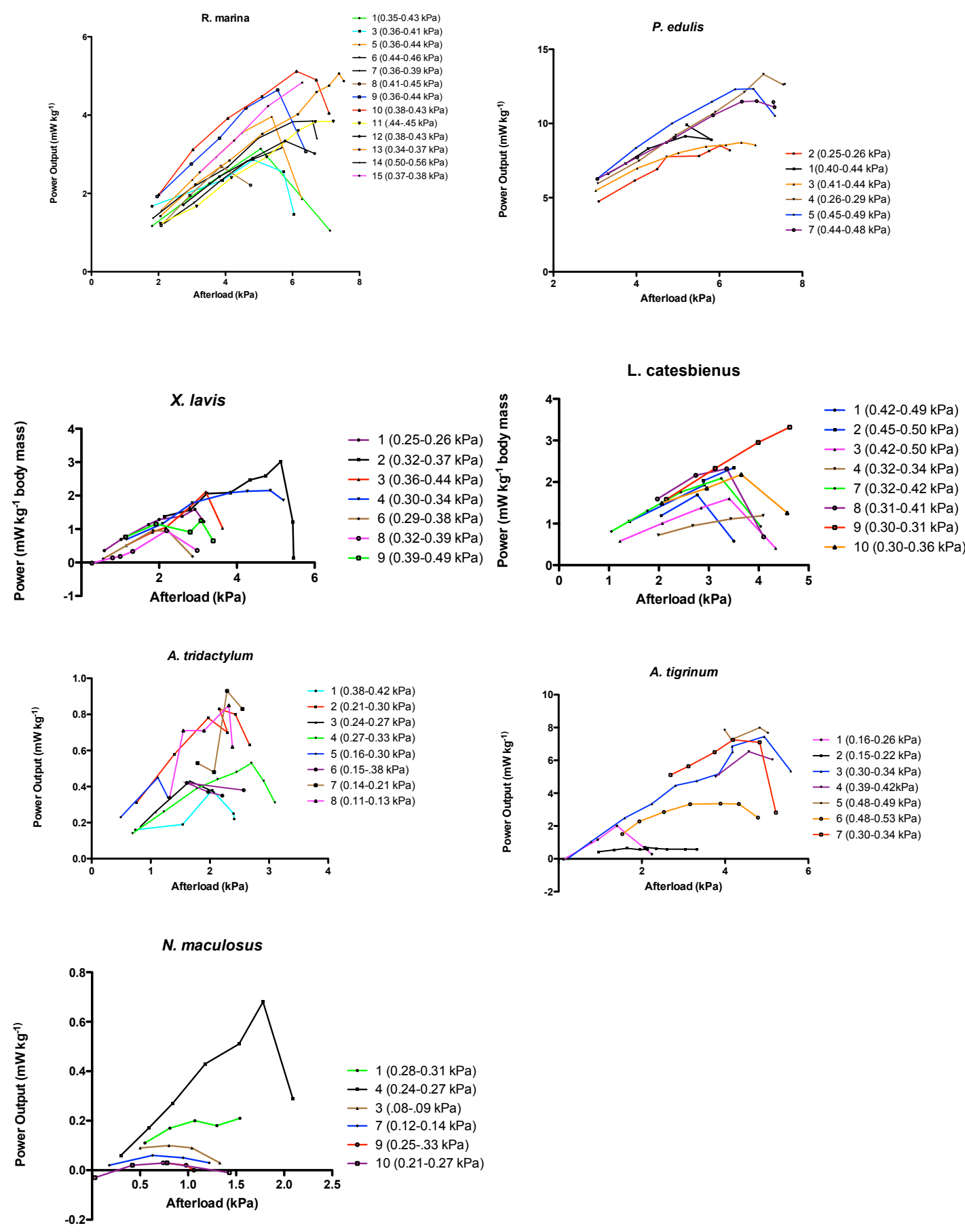

Figure 8. The effect of afterload on $P_{\max }$ for all seven species examined. Each line represents an individual. Parenthetical values in each key represent the rage of preloads in which each measurement was taken. 

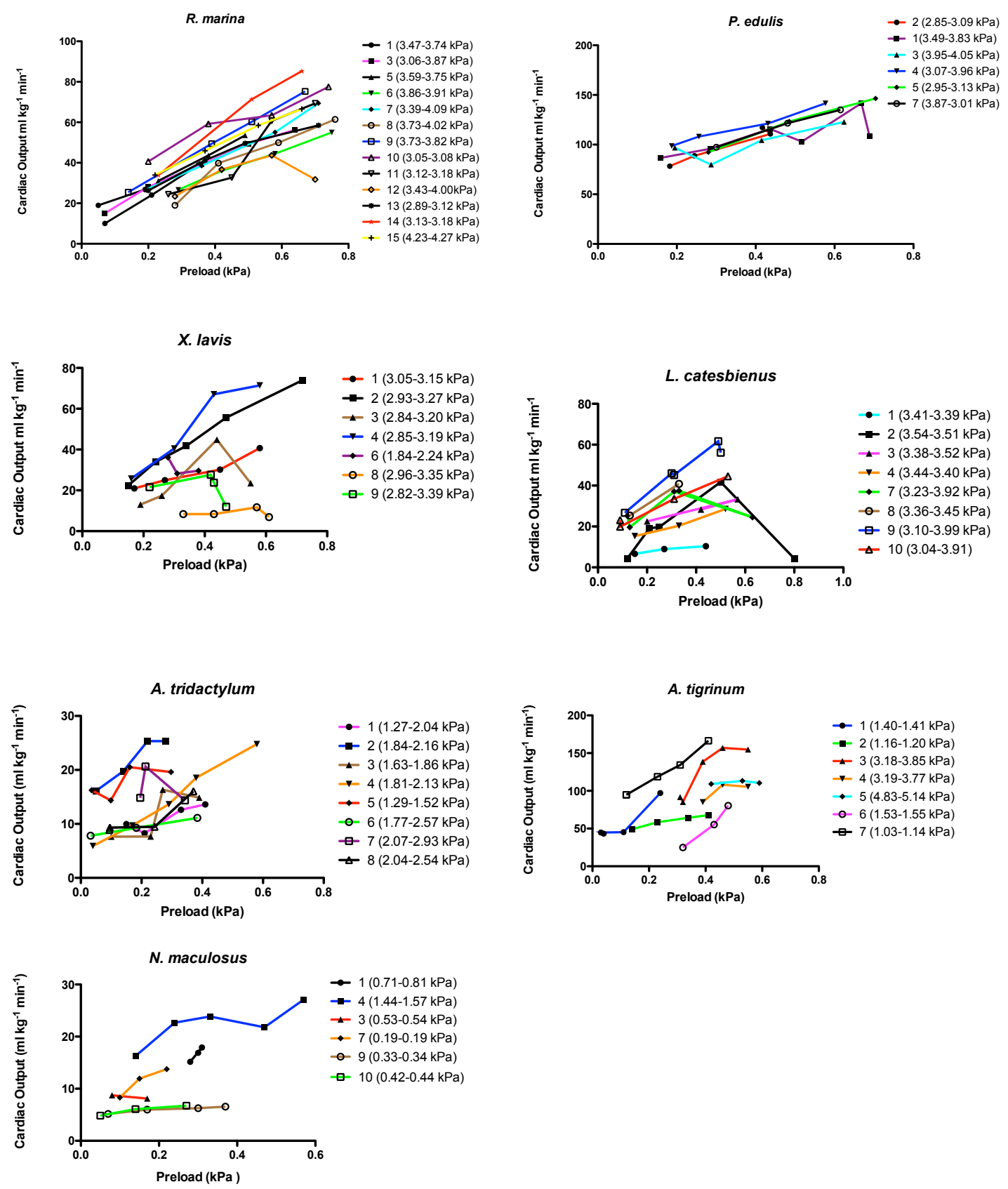

Figure 9. The effect of preload on cardiac output for all seven species examined. Each line represents an individual. Parenthetical values in each key represent the rage of afterloads in which each measurement was taken. 

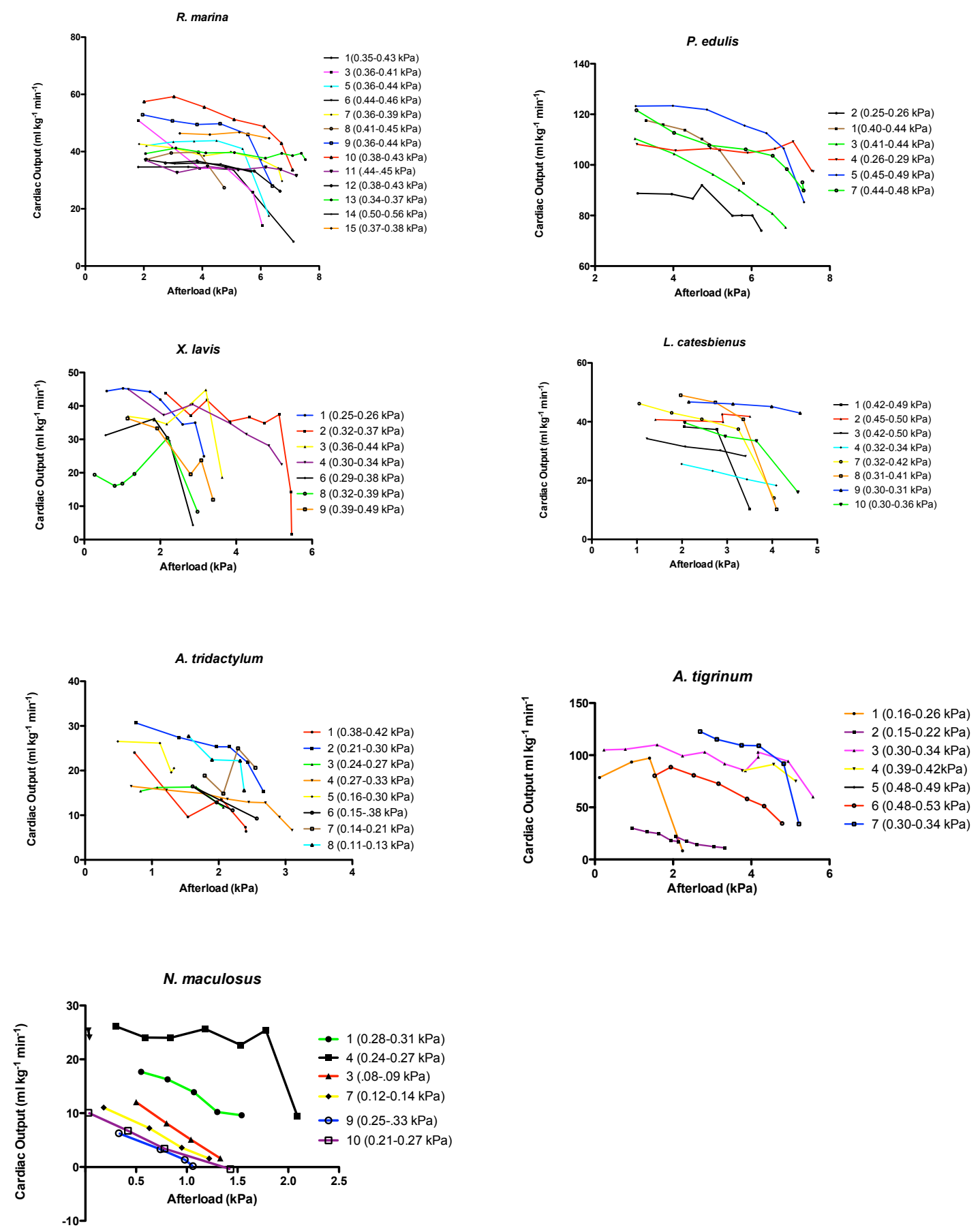

Figure 10. The effect of afterload on cardiac output for all seven species examined. Each line represents an individual. Parenthetical values in each key represent the rage of preloads in which each measurement was taken. 

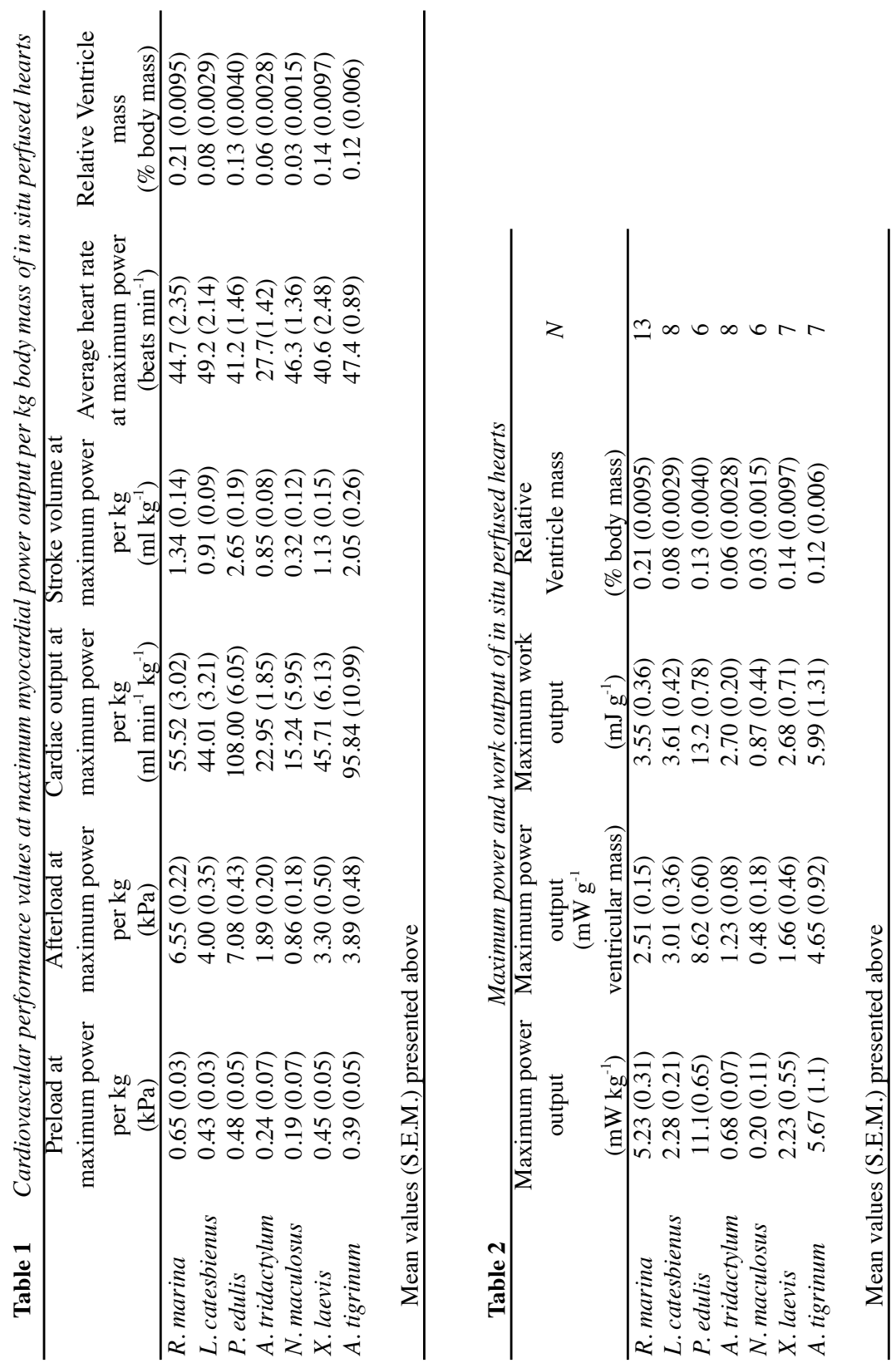


\section{References}

Acierno, R, C Agnisola et al. "Myoglobin Enhances Cardiac Performance in Antarctic Icefish Species That Express the Protein.” Am J Physiol 273.1 Pt 2 (1997): R100-6.

Acierno, R, A Gattuso et al. "The Isolated and Perfused Working Heart of the Frog, Rana Esculenta: An Improved Preparation." General Pharmacology: The Vascular System 25.3 (1994): 521-26.

Agnisola, C., R. Acierno et al. "In Vitro Cardiac Performance in the Sub-Antarctic Notothenioids Eleginops Maclovinus (Subfamily Eleginopinae), Paranotothenia Magellanica, and Patagonotothen Tessellata (Subfamily Nototheniinae)."

Comparative Biochemistry and Physiology Part A: Physiology 118.4 (1997): 143745.

Agnisola, C., R. Venzi et al. "Coronary Flow-Pressure Relationship in the Working Isolated Fish Heart: Trout (Oncorhynchus Mykiss) Versus Torpedo (Torpedo Marmorata)." Philosophical Transactions of the Royal Society B: Biological Sciences 343.1304 (1994): 189-98.

Axelsson, M, and I Wahlqvist.... "Cardiovascular Regulation in the Mudpuppy Necturus Maculosus At Rest and During Short Term Exercise.” Experimental biology 48.5 (1989): 253-59.

Bishop, C.M. "Heart Mass and the Maximum Cardiac Output of Birds and Mammals: Implications for Estimating the Maximum Aerobic Power Input of Flying Animals." Philosophical Transactions of the Royal Society B: Biological Sciences 352.1352 (1997): 447-56.

Blakemore, C., A. Cuthbert et al. The Oxford Companion to the Body. En.Scientificcommons.Org, Oxford: Oxford Univ. Press, 2001.

Blank, JM, and CJ Farwell. "Influence of Swimming Speed on Metabolic Rates of Juvenile Pacific Bluefin Tuna and Yellowfin Tuna." Physiological Bichemistry and Zoology 80.2 (2007): 167-77.

Blank, JM, JM Morrissette et al. "Effects of Temperature, Epinephrine and $\mathrm{Ca}(2+)$ on the Hearts of Yellowfin Tuna (Thunnus Albacares).” J Exp Biol 205.Pt 13 (2002): 1881-88.

Blank, JM, JM Morrissette, and CJ Farwell.... "Temperature Effects on Metabolic Rate of Juvenile Pacific Bluefin Tuna Thunnus Orientalis." Journal of experimental biology 210 (2007): 4254-61.

Blank, JM, JM Morrissette et al. "In Situ Cardiac Performance of Pacific Bluefin Tuna Hearts in Response to Acute Temperature Change." J Exp Biol 207.Pt 5 (2004): 881-90.

Brett, JR. "The Metabolic Demand for Oxygen in Fish, Particularly Salmonids, and a Comparison With Other Vertebrates.” Respiration physiology 14.1-2 (1972): 15170 .

Burgetz, I.J., A. Rojas-Vargas et al. "Initial Recruitment of Anaerobic Metabolism During Sub-Maximal Swimming in Rainbow Trout (Oncorhynchus Mykiss)." Journal of Experimental Biology 201 (1998): 2711-21.

Clack, JA. "Devonian Climate Change, Breathing, and the Origin of the Tetrapod Stem Group." Integrative and Comparative Biology 47.4 (2007): 510-23. 
Claireaux, G, D Mckenzie et al. "Linking Swimming Performance, Cardiac Pumping Ability and Cardiac Anatomy in Rainbow Trout." The Journal of Experimental Biology 208.10 (2005): 1775-84.

Clark, T.D., E. Sandblom et al. "Circulatory Limits to Oxygen Supply During an Acute Temperature Increase in the Chinook Salmon (Oncorhynchus Tshawytscha).” American Journal of Physiology-Regulatory, Integrative and Comparative Physiology 295.5 (2008): R1631.

Conklin, D, A Chavas, and D Duff.... "Cardiovascular Effects of Arginine Vasotocin in the Rainbow Trout Oncorhynchus Mykiss." Journal of experimental Biology 200 (1997): 2812-32.

Davidson, Glen W., and Peter S. Davie. "Mechanical Efficiency of Isolated in Situ Perfused Hearts of the Eel Anguilla Australis." Comparative Biochemistry and Physiology - Part A: Molecular \& Integrative Physiology 128.1 (2001): 167-75.

Davie, Peter S., and Anthony P. Farrell. "Cardiac Performance of an Isolated Heart Preparation From the Dogfish : The Effects of Hypoxia and Coronary Artery Perfusion." Can. J. Zool. 69.7 (1991): 1822-28.

Dewar, H. "Studies of Tropical Tuna Swimming Performance ina Large Water Tunnel." Journal of Experimental Biology 92 (1994): 13-31.

Farmer, C. "Air-Breathing During Activity in the Fishes Amia Calva and Lepisosteus Oculatus.” Journal of experimental biology 201 (1998): 943-48.

Farrell, AP. "From Hagfish to Tuna: A Perspective on Cardiac Function in Fish." Physiological Zoology 64.5 (1991): 1137-64.

Farrell, AP, JA Johansen, and RK Suarez. "Effects of Exercise-Training on Cardiac Performance and Muscle Enzymes in Rainbow Trout, Oncorhynchus Mykiss." Fish Physiology and Biochemistry 9.4 (1991): 303-12.

Farrell, AP, and KR MacLeod. "Cardiac Performance in the in Situ Perfused Fish Heart During Extracellular Acidosis: Interactive Effects of Adrenaline.” Journal of experimental biology 107 (1983): 415-29.

Farrell, AP, and JAW Stecyk. "The Heart as a Working Model to Explore Themes and Strategies for Anoxic Survival in Ectothermic Vertebrates." Comparative Biochemistry and Physiology-Part A: Molecular \& Integrative Physiology 147.2 (2007): 300-12.

Farrell, AP, S Wood, and T Hart. "Myocardial Oxygen Consumption in the Sea Raven Hemitripterus Americanusl the Effect of Volume Loading, Pressure Loading, and Progressive Hypoxia." Journal of experimental biology 117 (1985): 237-50.

Franklin, CE, and M Axelsson. "The Intrinsic Properties of an in Situ Perfused Crocodile Heart." Journal of experimental biology 186 (1994): 269-88.

Franklin, Craig E. "Intrinsic Properties of an in Situ Turtle Heart (Emydura Signala) Preparation Perfused Via Both Atria." Comparative Biochemistry and Physiology Part A: Physiology 107.3 (1994): 501-07.

Franklin, Craig E., and Peter S. Davie. "Myocardial Power Output of an Isolated Eel (Anguilla Dieffenbachii) Heart Preparation in Response to Adrenaline." Comparative Biochemistry and Physiology Part C: Comparative Pharmacology 101.2 (1992): 293-98.

Gallaugher, PE, H Thorarensen et al. "Effects of High Intensity Exercise Training on 
Cardiovascular Function, Oxygen Uptake, Internal Oxygen Transport and Osmotic Balance in Chinook Salmon (Oncorhynchus Tshawytscha) During Critical Speed Swimming." The Journal of experimental biology 204.Pt 16 (2001): 2861.

Gamperl, AK, KJ Rodnick et al. "Metabolism, Swimming Performance, and Tissue Biochemistry of High Desert Redband Trout (Oncorhynchus Mykiss Ssp.)" Physiological Bichemistry and Zoology 75.5 (2002): 413-31.

Garofalo, F, S Imbrogno et al. "Cardiac Morpho-Dynamics in Rana Esculenta: Influence of Sex and Season." Comparative Bichemistry and Physiology-Part A: molecular and integrative physiology 145.1 (2006): 82-89.

Gollock, MJ, S. Currie et al. "Cardiovascular and Haematological Responses of Atlantic Cod (Gadus Morhua) to Acute Temperature Increase." Journal of Experimental Biology 209.15 (2006): 2961-70.

Gooding, RM, WH Neill, and AE Dizon. "Respiration Rates and Low-Oxygen Tolerance Limits in Skipjack Tuna, Katsuwonus Pelamis." Fish. Bull. Fish Wildlife services (1981): 31-48.

Graham, JB, and HJ Lee. "Breathing Air in Air: In What Ways Might Extant Amphibious Fish Biology Relate to Prevailing Concepts About Early Tetrapods, the Evolution of Vertebrate Air Breathing, and the Vertebrate Land Transition?" Physiological and Biochemical Zoology 77.5 (2004): 720-31.

Graham, MS, and AP Farrell. "The Effect of Temperature Acclimation and Adrenaline on the Performance of a Perfused Trout Heart." Physiological zoology 62.1 (1989): $38-61$.

Hillman, S, P Withers, and P Kimmel. "Plasma Catecholamines With Hemorrhage in the Bullfrog, Rana Catesbeiana." Journal of Experimental Zoology Part A: Comparative Experimental Biology 280.2 (1998): 174-81.

Hillman, S.S., P.C. Withers, and R.C. Drewes. "Correlation of Ventricle Mass and Dehydration Tolerance in Amphibians.” Herpetologica 56.4 (2000): 413-20.

Hillman, SS. "Dehydrational Effects on Cardiovascular and Metabolic Capacity in Two Amphibians." Physiological Zoology (1987)

Hoagland, TM, L Jr Weaver et al. "Effects of Endothelin-1 and Homologous Trout Endothelin on Cardiovascular Function in Rainbow Trout." American Journal of Physiology 278.2 (2000)

Johnston, IA, N Fitch et al. "Morphometric and Ultrastructural Features of the Ventricular Myocardium of the Haemoglobin-Less Icefish Chaenocephalus Aceratus." Comparative Biochemistry and Physiology Part A: Phsyiology 76.3 (1983): 475-80

Kohl, Z. (2009) Measurement and correlates of interspecific differences in systemic and pulmonary vascular resistance. M.S. Thesis. Portland State University. U.S.A.

Lighton, JRB. "Aerial Co2 and O2 Exchange During Terrestrial Activity in an Amphibious Fish, Alticus Kirki (Blenniidae).” Copeia 1989.3 (1989): 723-27.

Lowe, WH. "What Drives Long-Distance Dispersal? A Test of Theoretical Predictions." Ecology 90.6 (2009): 1456-62.

Olson, KR, DJ Conklin, and L Jr Weaver. "Cardiovascular Effects of Homologous Bradykinin in Rainbow Trout." American Journal of Physiology 272.4 (1997): R1112-R1120. 
Ostádal, B. "Developmental Relationships Between the Structure, Blood Supply and Metabolic Pattern of the Vertebrate Heart." Cor et vasa 20.6 (1979): 380-86.

Pough, FH. "The Advantages of Ectothermy for Tetrapods." American Naturalist 115.1 (1980): 92-112.

Romero, SMB, and AF Pereira... "Effects of Exercise on Plasma Catecholamine Levels in the Toad, Bufo Paracnemis: Role of the Adrenals and Neural Control." Journal of Experimental Zoology Part A: Comparative Experimental Biology 301A.12 (2004): 911-18.

Sandblom, E., M. Axelsson, and A.P. Farrell. "Central Venous Pressure and Mean Circulatory Filling Pressure in the Dogfish, Squalus Acanthias: Adrenergic Control and the Role of the Pericardium." American Journal of Physiology-Regulatory, Integrative and Comparative Physiology 291 (2006): 1465-73.

Santer, RM, MG Walker, and L Emerson... "On the Morphology of the Heart Ventricle in Marine Teleost Fish (Teleostei)." Journal of Biochemistry and Physiology Part A: Physiology 76.3 (1983): 453-57.

Schmidt-Nielsen, K. "Locomotion: Energy Cost of Swimming, Flying, and Running." Science 177.45 (1972): 222-28.

Smits, AW, and Flanagin J. "Bimodal Respiration in Aquatic and Terrestrial Apodan Amphibians." American Zoologist 34 (1994): 247-63.

Taigen, TL, and CA Beuchat. "Anaerobic Threshold of Anuran Amphibians." Physiological Zoology 57.6 (1984): 641-47.

Tiitu, V. "Morphology and Fine Structure of the Heart of the Burbot, a Cold Stenothermal Fish." Journal of fish biology 61.1 (2002): 106-21.

Tota, B., R. Acierno, and C. Agnisola. "Mechanical Performance of the Isolated and Perfused Heart of the Haemoglobinless Antarctic Icefish Chionodraco Hamatus: Effects of Loading Conditions and Temperature." Philosophical Transactions: Biological Sciences 332.1264 (1991): 191-98.

Wells, HG. A Short History of the World. New York: Macmillan, 1922.

Withers, PC, and SS Hillman. "Allometric and Ecological Relationships of Ventricle and Liver Mass in Anuran Amphibians.” Functional Ecology 15.1 (2001): 60-69. 